\title{
Soil property variability in a humid natural Mediterranean environment: La Rioja, Spain
}

\author{
Variabilidad de las propiedades del suelo en ambiente mediterráneo húmedo: La Rioja, \\ España \\ Variabilidade espacial das propriedades do solo em ambiente húmido Mediterrâneo: La \\ Rioja, Espanha
}

\section{AUTHORS}

Iñigo $V^{1}$

Andrades M.S.

\section{Alonso- \\ Martirena J.I.}

Marín A.

\section{Jiménez-Ballesta \\ R. ${ }^{\circledR 2}$ \\ raimundo.jimenez@} uam.es

(a) Corresponding Author

${ }^{1}$ Dpto. de Agricultura y Alimentación. Complejo Científico Tecnológico. Universidad de La Rioja. C/ Madre de Dios, 51. 26006 Logroño. Spain.

2 Dpto. de Geología y Geoquímica. Campus Universitario de Cantoblanco. Universidad Autónoma de Madrid. 28049 Madrid. Spain.
Received: 05.10.2011 | Revised: 06.02.2012 | Accepted: 09.02.2012

\begin{abstract}
Estimating the spatial variability of soil properties is significant for evaluating environmental impacts. For example, many soil properties are directly used in the modelling of environmental processes such as global climate change. These aspects have not previously been studied at this level in La Rioja (a region of Spain with a humid Mediterranean environment). The intention of this study was to provide quantitative information on soil assessment and mapping methods for natural soils in a humid Mediterranean environment. The properties considered included: $\mathrm{pH}$ and organic matter, calcium carbonate and clay contents. For testing, samples were selected from several different soil types which, in theory, were only affected by pedogenetic processes and had developed on different parent materials. More than half of the samples did not contain any $\mathrm{CaCO}_{3}$, while the rest of the samples presented a variety of $\mathrm{CaCO}_{3}$, forms, with high percentages being present in certain cases (up to $65 \%$ on the surface). It was possible to establish two different areas: one predominantly acidic and the other principally basic. The predominately basic samples were due to the high percentage of carbonate in the parent materials. The clay content on the surface was similar to that in the subsurface layers. Finally, the organic matter contents in the uppermost layers presented average values of $3.9 \%$, with a range of from 0.3 to $17.5 \%$. The major variations in soils were determined by soil type (therefore by soil forming processes), parent material composition, and vegetation type. This study reveals that these methods are useful to determine the spatial distribution of some soil properties in undisturbed soils. The contour maps of soil property variability could be used to improve future sampling designs and management decisions.
\end{abstract}

\section{RESUMEN}

La estimación de la variabilidad espacial de las propiedades del suelo es importante para evaluar los impactos ambientales o en el modelado de procesos ambientales. En este trabajo se aborda la cuantificación y evaluación de algunas propiedades de suelos ( $p H$, carbonato cálcico, materia orgánica y el contenido en arcilla) de ambiente mediterráneo húmedo en La Rioja (España), un estudio que no habia sido previamente abordado a este nivel en esta región. Para este propósito se seleccionaron muestras de suelos teóricamente afectados solamente por procesos edafogenéticos y desarrollados sobre varios materiales de partida. Más de la mitad de las muestras no tienen carbonatos y las que tienen muestran contenidos variables, alcanzando hasta el 65\%. En función del pH se pueden 
establecer dos áreas: una ácida y otra básica. El contenido en arcilla en superficie es similar al de profundidad. Finalmente, el contenido en material orgánica presenta un valor medio de 3,9\% en superficie, con un rango que oscila entre 0,3 y 17,5\%. Las mayores variaciones se interpretan en función del tipo de suelo (y por tanto de los procesos de formación), composición del material originario y tipo de vegetación. El estudio revela que este método es útil para determinar la distribución espacial de algunas propiedades de suelos naturales y de este modo caracterizar el estatus de estas propiedades a la escala estudiada. Los mapas elaborados pueden ser utilizados en futuros muestreos de suelos y en la toma de decisiones sobre manejo de los mismos.

\section{RESUMO}

A estimativa da variabilidade espacial das propriedades do solo é importante para avaliar impactos ambientais ou na modelação de processos ambientais. Este artigo aborda a quantificação e avaliação de algumas propriedades do solo ( $p H$, teor em carbonato de cálcio, matéria orgânica e teor em argila) em ambiente mediterrânico búmido: La Rioja (Espanha). Para este efeito, foram selecionadas amostras de solo teoricamente afetadas apenas por processos edafogeneticos e desenvolvidas a partir de diferentes materiais de origem. Mais de metade das amostras não têm carbonatos e as que têm apresentam um conteúdo variável, podendo chegar até $65 \%$. Em função do pH podem estabelecer-se duas áreas: uma ácida e uma básica. O teor de argila à superfície é idêntico ao teor em profundidade. Finalmente, o teor em matéria orgânica apresenta um valor médio de 3,9\% à superfície, variando numa gama entre 0,3 e 17,5\%. As maiores variações são atribuídas ao tipo de solo, composicão do material de origem e vegetacão. Este estudo revela que este método é útil para determinar a distribuição espacial de algumas propriedades dos solos naturais e, deste modo, caracterizar o estado dessas propriedades para a escala estudada. Os mapas produzidos podem ser utilizados em futuras amostragens de solo e na tomada de decisões sobre a gestão das mesmas.

KEYWORDS

Natural soils, spatial variability, humid

Mediterranean environment

PALABRAS

CLAVE

Suelo natural, variabilidad espacial, clima mediterráneo húmedo

PALAVRAS-

CHAVE

Solo natural, variabilidade espacial, o ambiente húmido

Mediterrânico 


\section{Introduction}

In any region, the formation of soils is influenced by many factors, including: the parent material, climate and resulting secondary materials, the vegetation, and the history of local land use. These factors vary from place to place and contribute to the spatial variation of soil properties. The quantification of the magnitude, location and causes of spatial variability are all essential parts of soil surveys.

Estimating the spatial variability of physical and chemical soil properties is a prerequisite for soil and crop-specific management (Sharma et al. 2011) and is important for land management and the construction of an ecological environment (Wang and Shao 2011). Data on soil water and organic matter content are critical inputs for continental and global simulations of climate, biogeochemical cycles and vegetation and their respective responses to change. Soil is the largest terrestrial store for C (Post et al. 1990; Batjes 1996; Batjes 1997); the initialization of soil moisture is critical to the results of global climate models (Walker and Houser 2001).

In studies that address the feasibility of measurement and map development, one recurring limitation is the failure to appropriately evaluate map accuracy: the consistency between predicted and observed attribute values for any given location within the mapped region (Brouder et al. 2005). For soil pH, Mueller et al. (2001) presented the most complete review of the impacts of both soil sampling densities and interpolation techniques on map quality. They concluded that the commercially used $100 \mathrm{~m}$ grid was grossly inadequate for predicting within-field variation in soil $\mathrm{pH}$, although more intensive soil sampling (still within commercial constraints) appeared to offer a slight improvement. They also reported that the chosen method of interpolation (ID, kriging, or nearest neighbour analysis) had little impact on the final outcome. Laslett et al. (1987) evaluated numerous methods for mapping soil $\mathrm{pH}$ and, based on prediction sums of squares, concluded that both $\mathrm{ID}_{P=2}$ and isotropic kriging performed well for water and $\mathrm{CaCl}_{2} \mathrm{pH}$.
Recent, soil science literature contains many examples of kriging being used to estimate soil variables at unsampled sites from data referring to adjacent sample points. These techniques can be used to generate contour maps of soil properties from grid samples. On the other hand, there are also examples in which the threshold values of soil properties are important for soil management. Choosing an optimal interpolation technique for estimating soil properties at unsampled locations is an important issue in site-specific management. But when a land manager wants to interpret a kriged map of a particular soil property and to compare it with critical threshold values, the uncertainty of these estimates becomes an important consideration.

Informed soil protection or conservation decisions cannot be made without maps showing land properties (Henry et al. 2009). Most geostatistical studies in soil science aim to estimate soil properties in previously unsampled locations and to map them. The main objectives of this study were to provide a basic understanding, using a non-traditional technique, and to assess the spatial distribution of certain soil properties in natural (undisturbed) soils in a humid Mediterranean environment such as La Rioja, Spain (Figure 1). As a result, soil samples were selected from several different soil types that, in theory, were only affected by pedogenetic processes and developed on different parent materials.

\section{Materials and Methods}

\section{Study area}

The area studied, part of La Rioja (Figure 1), is located on the Iberian Peninsula, between latitudes $541^{\circ} 55^{\prime}$ and $42^{\circ} 39^{\prime}$ north and the longitudes $1^{\circ} 41^{\prime}$ and $3^{\circ} 09^{\prime}$ west. The maximum altitude was $2271 \mathrm{~m}$ and the minimum was 262 $\mathrm{m}$. The area studied was $5034 \mathrm{~km}^{2}$ wide $(1 \%$ of the total area of Spain). 


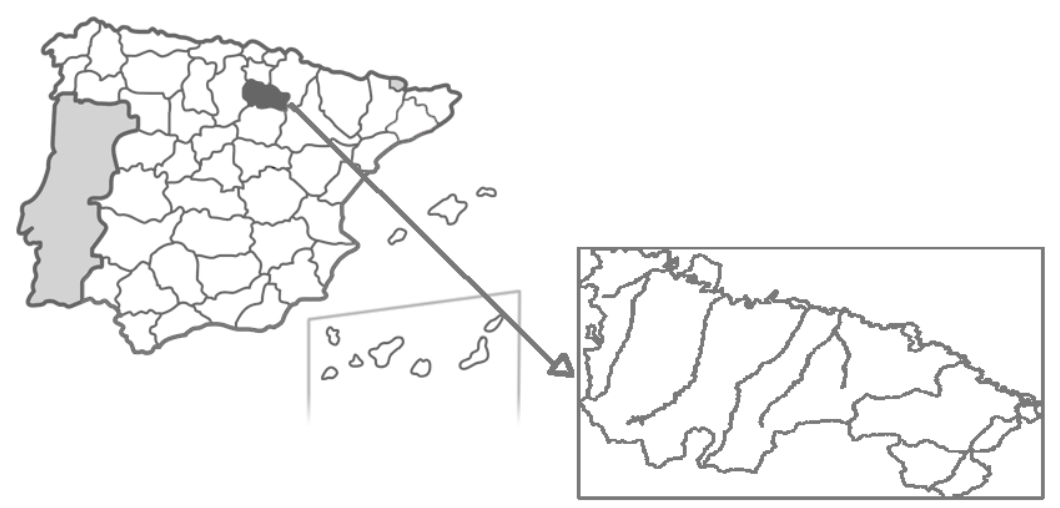

Figure 1. Map showing the location of the area studied (La Rioja, Spain).

Geographically speaking, this area includes two clearly different sub-areas: a valley area to the north and a mountainous area to the south. This implies a noticeable contrast in topography, with the two sub-areas containing different morphostructural units: the Depression of the Ebro River and the Iberian System. The area contains various lithological units (Figure 2) that can be divided into three important geological groups: The Demanda and Urbión Mountain Range; the Cameros Mountain Range; and the Rioja Gully.
The most representative Palaeozoic rocks in this area are the quartzites and slate and shale series. The sedimentation process during the Triassic Period started with red sandstone, was followed by sandy dolomites and ended with gypsums and marls. Carbonated materials from the Jurassic Period can also be found in the area. Throughout the Quaternary Period, terraces and glacis were created (Casas et al. 2001; García Ruiz 1994).

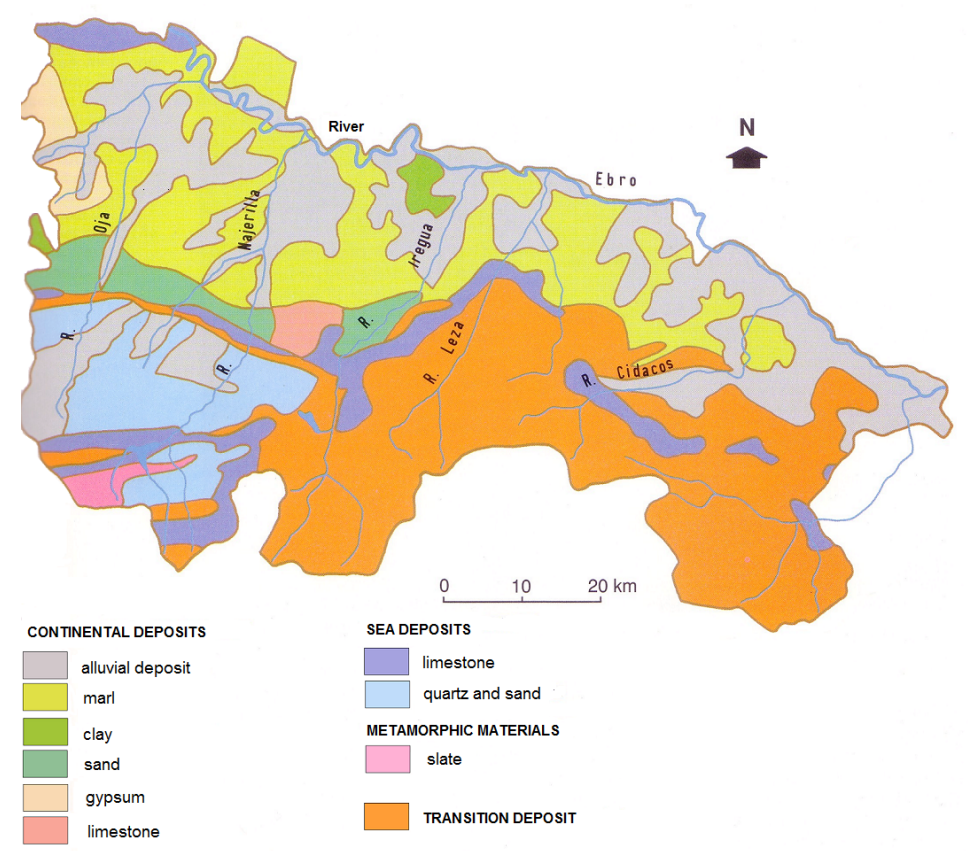

Figure 2. Lithology of La Rioja (from García-Ruiz 1994). 
From the climatic point of view, this is a very complex region. This is largely due to its peculiar geographical situation: it is subject to diverse climatic effects and its rugged orography (Núñez and Martínez 1991). It has a mainly continental climate, but also receives influences from the Atlantic and Mediterranean seas and the previously mentioned topography. The division of this territory into two major blocks makes the climate vary greatly from one area to another (from the valley area to the mountainous area). These differences are particularly noticeable with respect to the distributions of temperature (Figure 3) and rainfall (Figure 4). The average annual temperature in La Rioja is $12{ }^{\circ} \mathrm{C}$, with January being the coldest month, with an average temperature of $5^{\circ} \mathrm{C}$, and July being the warmest, with an average temperature of $21^{\circ} \mathrm{C}$. Rainfall varies from $400 \mathrm{~mm}$ year ${ }^{-1}$ to $1200 \mathrm{~mm}$ year $^{-1}$.

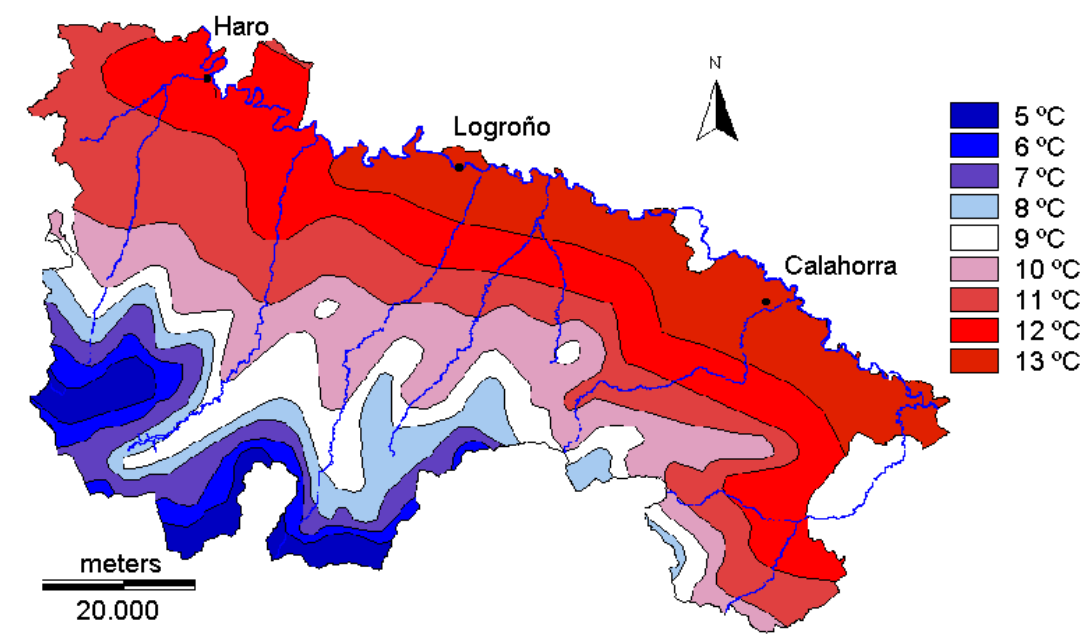

Figure 3. Temperature $\left({ }^{\circ} \mathrm{C}\right)$ distribution in La Rioja (Spain).

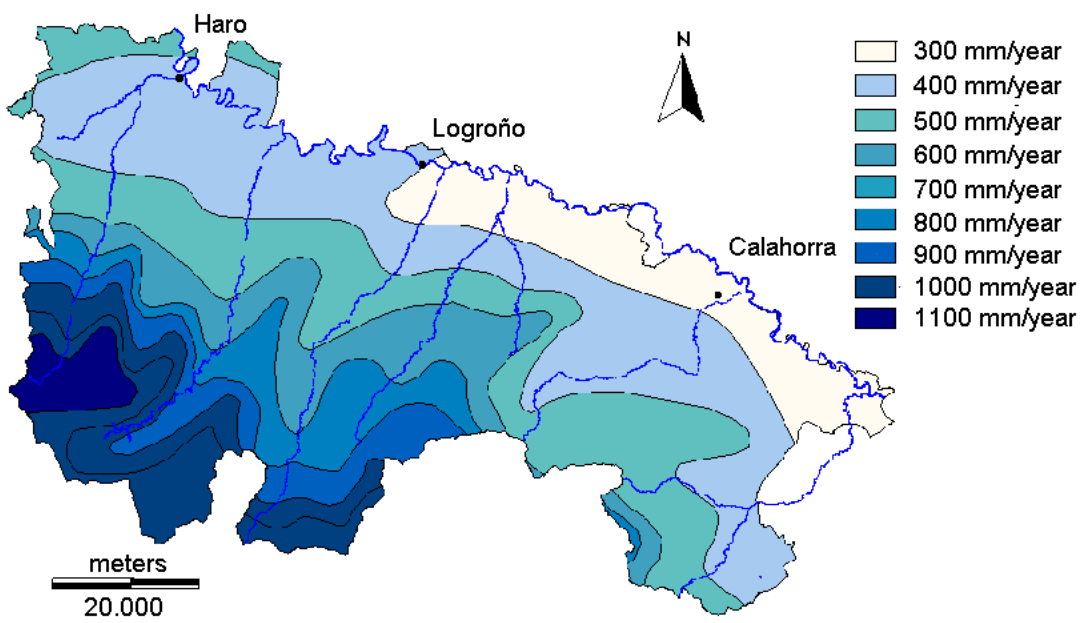

Figure 4. Rainfall (mm year ${ }^{-1}$ ) distribution in La Rioja (Spain). 
According to Fernández-Aldana et al. (1989), the forest vegetation of La Rioja includes: evergreen Sclerophyllous woods, where the dominant species is Quercus ilex ssp ballota; Quercus pyrenaica; meso-xerophylous oak woods, adapted to dry environments; beech woods (Fagus sylvatica); mixed woodland, including deciduous trees such as Quercus petraea; birch woods; forests of wild pine (Pynus sylvestris); river bank forests; and the Ebro Groves, which contain the typical vegetation found next to rivers, such as black poplars (Populus nigra), alders (Alnus glutinosa), white willows (Salix alba), ash (Phaxinus angustifolia) and some white poplars (Populus alba); reforestations, although these may not be natural communities of original species but rather plantations of single species. With respect to thicket formation, it is relevant to note the following (Arizaleta et al. 1990): Quercus coccifera; the Mediterranean basal thicket, Genista scorpius, Lavandula latifolia, and Thymus vulgaris; Mediterranean mountain thicket, mainly Ononido-Rosmarinetea; foothill heaths; and Genista hispanica, Lavandula latifolia and Genista scorpius. Buxus sempervirens, Cistus laurifolios; Genista florida and Cytisus scoparius are the most common bush species, while the heath vegetation includes fields of Iberian shrubs such as Genisto pilosae-Ericetum aragonensis, and crawling juniper is also found.

Many of these areas are protected under European Community regulation (Council Directive 92/43/
EEC on the Conservation of Natural Habitats and of Wild Fauna and Flora and Law 4/98), while six IBAs (Important Bird Areas) have been designated and proposals have been presented to add six $\mathrm{SCl}$ (Sites of Community Importance) to the Natura 2000 programme, amongst other measures.

The different lithologies, landforms, climates and types of vegetation -which are the main soil forming factors- have produced a great variety of soils both in the valley area and in the mountainous area. According to the FAO-ISRIC-ISSS (2006), the following soil types of soils are present in the area studied: Fluvisols, (Haplic and Petric) Calcisols, (Calcaric and Eutric) Regosols, (Dystric, Eutric, Lithic, and Rendsic) Leptosols, (Calcaric and Dystric) Cambisols, (Luvic and Calcic) Kastanozems, (Haplic) Alisols, and (Haplic) Luvisols.

\section{Sampling procedure}

The selected sites were located across the Community of La Rioja (Spain) and represent various environmental conditions and typical soils of this vast area. 125 sampling points were selected from 125 georeferenced locations, corresponding to 125 natural (undisturbed) soil profiles, randomly distributed across the mountainous part of La Rioja. All the soil types found in the region were included. The sampling locations are shown in Figure 5.

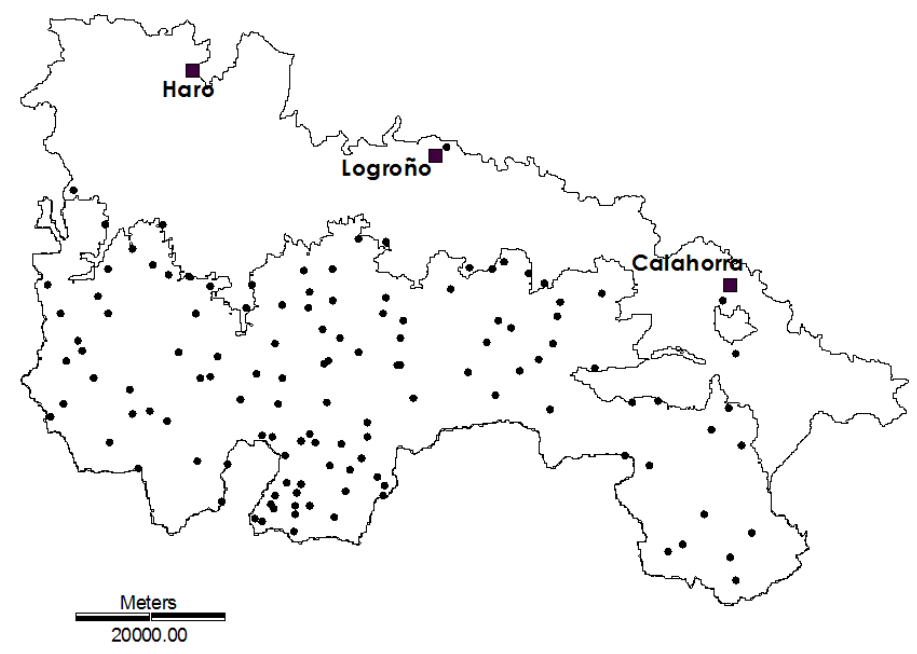

Figure 5. Distribution of sampling locations. 
The number of soil samples needed to represent the variability observed in the field has been matter of discussion since at least the 1920s (Lindsley and Bauer 1929). Sample locations can be chosen using (a) haphazard sampling, (b) judgment sampling, or (c) probability sampling. We used judgment sampling (also termed purposive sampling) because it involves the selection of sampling points based on the knowledge of the researcher, and also because judgment sampling can result in accurate estimates of population parameters such as means. Background sampling should also be carried out to measure the variability within the background area. This implies selecting several sites, each of which should be sampled. Pitard (1989) and Ingamells (1974) outline procedures for evaluating data collected over a wide area in order to identify background levels. One very simple approach for estimating background levels is to examine data from a large set of soil samples relating to the area under investigation. The lowest value, or lowest class of values, observed is likely to be close to the actual background level.

Two parts of the soil are important for the environmental researcher: surface and subsurface. The surface layer $(0-6 \mathrm{~cm}$, e.g.) reflects the deposition of airborne pollutants and especially recently deposited ones and pollutants that do not move downward through the soil profile due to attachment to soil particles. Samples can also be collected using a core sampling or auger device. In our case, we collected samples after soil profile description using excavations or trenches. The selected soil profiles were identified and described morphologically according to FAO Guidelines (FAO 2006).

The samples (defined as simple samples) were selected with the aim of reflecting the greatest possible variety of soils, parental materials, vegetation and climatic influences. The area studied fell within La Rioja's Natural Environment Special Protection Plan (PEPMAN). Two soil samples were collected for each location: one representative of the upper horizon (Ah 0-15 $\mathrm{cm})$ and the other relating to the underlying layer and the B, C and/or R horizons $(80-100 \mathrm{~cm})$. In all, a total of 250 samples were analyzed.

\section{Analytical methods}

All the soil samples were dried at room temperature $\left(25^{\circ} \mathrm{C}\right)$ to a constant weight. They were then carefully sieved through a $2 \mathrm{~mm}$ mesh and the coarser material was discarded. The remaining fine-earth fraction was then gently mixed until it appeared to be homogeneous. Aliquots of this fraction were randomly selected for chemical and physical-chemical analysis. These analytical determinations were carried out according to SCSUSDA (1972). Soil pH was measured in $\mathrm{H}_{2} \mathrm{O}$ and in $0.1 \mathrm{M} \mathrm{KCl}$ using a 1:2.5 soil/solution ratio. For calcium carbonate determination, $\mathrm{CO}_{2}$ content was measured in a calcimeter. Soil organic matter was determined by potassium dichromate oxidation and titration of the remaining dichromate with ammonium ferrous II sulphate (Anne 1945). Soil texture was determined using the hydrometer method (Gee and Bauder 1986). All samples were extracted and analysed in triplicate.

\section{Statistical methods}

GIS software has been increasingly used in environmental studies (Ozores et al. 1994; Corwing et al. 1996; Ebbinghaus et al. 1997; Facchinelli et al. 2001; Ferreira et al. 2001; Lyn 2002). It has been specifically used to calculate small-scale soil physical-chemical properties and to predict the kind of treatment (such as fertilizing) that best suits a particular segmented estate (specific site management) (Bardossy and Lehman 1998; Bocchi et al. 2000; Castrignanò et al. 2000; Lapen et al. 2001).

Inverse distance weighting (IDW) was employed to delineate the spatial variation of soil properties: $\mathrm{pH}$, organic matter, calcium carbonate, and clays. This is a simple spatial interpolant that often yields satisfactory results (Robinson and Matternicht 2006). The formula of this exact interpolator is (Burrough and McDonnell 1998):

$\widehat{z}\left(x_{0}\right)=\frac{\sum_{i=1}^{n} z\left(x_{i}\right) d_{i j}^{-\gamma}}{\sum_{i=1}^{n} d_{i j}^{-\gamma}}$

where $x_{0}$ is the estimation point and $x_{i}$ are the data points within a chosen neighbourhood. The weights $(r)$ are related to distance by $d_{i j}$, which is the distance between the estimation point and the data points. 


\section{Results and Discussion}

Spatial distribution of soil properties

Soil surveying and mapping are important operations since they play a key role in our knowledge of soil properties and how they can be used for agriculture, irrigation, urbanization and other land uses (Mohamed and Abdo 2011). The analysis and interpretation of the spatial variability of soil properties are key factors in sitespecific management (Pal et al. 2010).

After digitizing the boundaries of the maps of the area studied, the location of sampling points (Figure 5) and the $\mathrm{pH}$ and $\mathrm{CaCO}_{3}$, organic matter and clay contents of the corresponding nodes were identified according to their geographic coordinates in the Universal Transverse Mercator System. After analyzing the samples, the results were assigned to the map.
The variability of soil properties can be described by descriptive statistics such as the minimum, maximum and mean. To evaluate the raw data, the descriptive statistical summary of the $\mathrm{pH}, \mathrm{CaCO}_{3}$, clay and organic matter soil properties is presented in Table 1. According to the classification system proposed by Nielsen and Bouma (1985), a parameter is considered to exhibit: low variability if the $\mathrm{CV}$ is less than 0.1 ; moderate variability, if the $\mathrm{CV}$ is between 0.1 and 1; and high variability, if the $\mathrm{CV}$ is larger than 1. The soil properties of La Rioja varied greatly with location and their spatial variability (which is inherent in nature) was determined by soil processes (soil type), parent material composition and vegetation type.

Tabla 1. Statistics for the variables studied: $\mathrm{pH}, \mathrm{CaCO}_{3}(\%), \mathrm{O} . \mathrm{M}(\%)$ and clay (\%)

\begin{tabular}{lcccccccc} 
& \multicolumn{2}{c}{$\mathrm{pH}$} & \multicolumn{2}{c}{$\mathrm{CaCO}_{3}(\%)$} & \multicolumn{2}{c}{ O.M (\%) } & \multicolumn{2}{c}{ Clay (\%) } \\
& Surface & Subsurface & Surface & Subsurface & Surface & Subsurface & Surface & Subsurface \\
\hline Average & 6.5 & 6.7 & 5.8 & 8.4 & 3.9 & 0.6 & 29.3 & 28.8 \\
\hline Median & 6.3 & 6.3 & 0.0 & 0.0 & 3.0 & 0.4 & 27.6 & 26.1 \\
\hline $\begin{array}{l}\text { Standard } \\
\text { Dev. }\end{array}$ & 1.3 & 1.5 & 0.0 & 0.0 & 3.1 & 0.7 & 9.5 & 10.8 \\
\hline Minimum & 3.9 & 4.3 & 64.8 & 77.3 & 0.3 & 0.0 & 15.1 & 12.2 \\
\hline Maximum & 8.7 & 9.5 & 0.0 & 0.0 & 17.5 & 3.7 & 68.4 & 68.0 \\
\hline Statistic (D) & 0.14 & 0.15 & 0.0 & 0.0 & 0.17 & 0.20 & 0.11 & 0.13 \\
\hline Skewness & 0.07 & 0.23 & 4.8 & 7.8 & 1.73 & 1.89 & 0.90 & 1.23 \\
\hline Kurtosis & -1.30 & -1.51 & 24.0 & 39.4 & 4.10 & 4.08 & 2.03 & 1.50 \\
\hline
\end{tabular}

O.M.: Organic matter

Tabla 2. Comparison between surface and subsurface statistics

\begin{tabular}{lccccc} 
& Correlation & Average & Low interval & Upper interval & $t$ \\
\hline pH Surface - pH Subsurface & 0.883 & -0.2 & -0.3 & 0.1 & -3.435 \\
\hline $\mathrm{CaCO}_{3}(\%)$ Surface - $\mathrm{CaCO}_{3}$ (\%) Subsurface & 0.720 & -2.6 & -4.7 & -0.6 & -2.555 \\
\hline O.M. (\%) Surface - O.M. (\%) Subsurface & 0.266 & 3.3 & 2.8 & 3.9 & 12.330 \\
\hline Clay (\%) Surface - Clay (\%) Subsurface & 0.508 & 0.4 & -1.4 & 2.3 & 0.465
\end{tabular}

O.M.: Organic matter 
Acidity: pH

Acidity is a soil property that has a devastating effect on crop growth because acidification causes a reduction in the availability of some essential nutrients (e.g. calcium and molybdenum) and also an increase in other nutrients to toxic levels (e.g. manganese and aluminium, Charman 2000). Soils with pHs below 4.5 in topsoil $\mathrm{CaCl}_{2}(0-10 \mathrm{~cm})$ are considered toxic to most crops (Fenton and Helyar 2000). Especially where rainfall is over $500 \mathrm{~mm}$, these soils often present problems of acidity further down the soil profile; the subsoil $(10-30 \mathrm{~cm})$ therefore also requires assessment.

Table 1 shows $\mathrm{pH}$ statistic parameters for the soil samples obtained from both the surface and at depth. The soils studied presented $\mathrm{pH}$ values ranging from very acidic to slightly basic or even alkaline, at depth (Porta et al. 2003). The average $\mathrm{pH}$ values in both cases were neutral. According to kriged estimates, the entire region has a $\mathrm{pH}$ of no lower than 4 (this means that plants that are sensitive to acidity should have no trouble establishing in these soils, resulting in poor production).

The Normal Kolmogorov-Smirnov (D) learning curve statistic is shown, as are the asymmetry and kurtosis values, which show whether the distribution follows a normal learning curve compared to the critical values. Both on surface and at depth, the D statistic was higher than the critical value for the same test (Zar 1996). In contrast, the asymmetry and kurtosis coefficients were lower than the critical value. $\mathrm{pH}$ distributions did not follow a normal learning curve distribution, though they did come close to it.

The Kolmogorov-Smirnov test shows that the distributions did not follow a normal learning curve. Both distributions present bi-normal distributions. This is most clearly observable when studying the $\mathrm{pH}$ in the lower layers of the soil profile because both distributions are easily differentiated: one with an acidic $\mathrm{pH}$, with an average value of 5.5 and the other with a basic $\mathrm{pH}$, with an average of 8.5 .
Mean $\mathrm{pH}$ values were compared in pairs for both the surface layer and at depth (Table 2). With this in mind, we calculated the differences between each pair of values and the statistical descriptors shown in Table 1. First, we correlated the mean values. The mean value obtained from the difference between the two distributions is presented together with the confidence intervals for the that mean value. In the last column, the t-statistic indicates whether the hypothesis was accepted or rejected: if the distributions are similar, the difference is close to 0 and the interval contains the number 0 (Miller and Miller 2002). As shown in Table 2, the surface pH values presented a strong correlation with the $\mathrm{pH}$ values at depth $\left(r^{2}=0.883, p<0.005\right)$, and the difference between the two mean values was significant, with the $\mathrm{pH}$ values being lower in the surface layers.

Figures $6 \mathrm{a}$ and $6 \mathrm{~b}$ show that the area studied could be divided into two different parts: an acidic area to the west and a predominantly basic area to the east (with the exception of the mountainous area around Cebollera). There were also some local variations in the distribution of $\mathrm{pH}$ due to topography and soil types.

The literature reviewed on the spatial scales of the soil test properties (Wollenhaupt et al. 1997) reported spatial $\mathrm{pH}$ ranges of 20 to $132 \mathrm{~m}$. Wollenhaupt et al. (1997) state that soil properties with low CVs tend to require less intensive soil sampling schemes; this implies that the spatial structure of soil pH should be easier to determine with fewer soil samples than that of other soil properties, including P and K. However, for soil acidity, the $\mathrm{CV}$ is used for the log transformation of the management objective, $\left[\mathrm{H}_{3} \mathrm{O}^{+}\right]$ and large differences in LR may accompany small changes in soil pH. Indeed, some of the studies cited above and the summary by McBratney and Pringle (1999) suggest that soil pH may exhibit one of the shortest spatial ranges of soil properties typically tested by producers. This suggests that more samples may be required to accurately characterize $\mathrm{pH}$ and $\mathrm{LR}$ spatial structure, especially when grid or other systematic soil sampling strategies are used. 
a

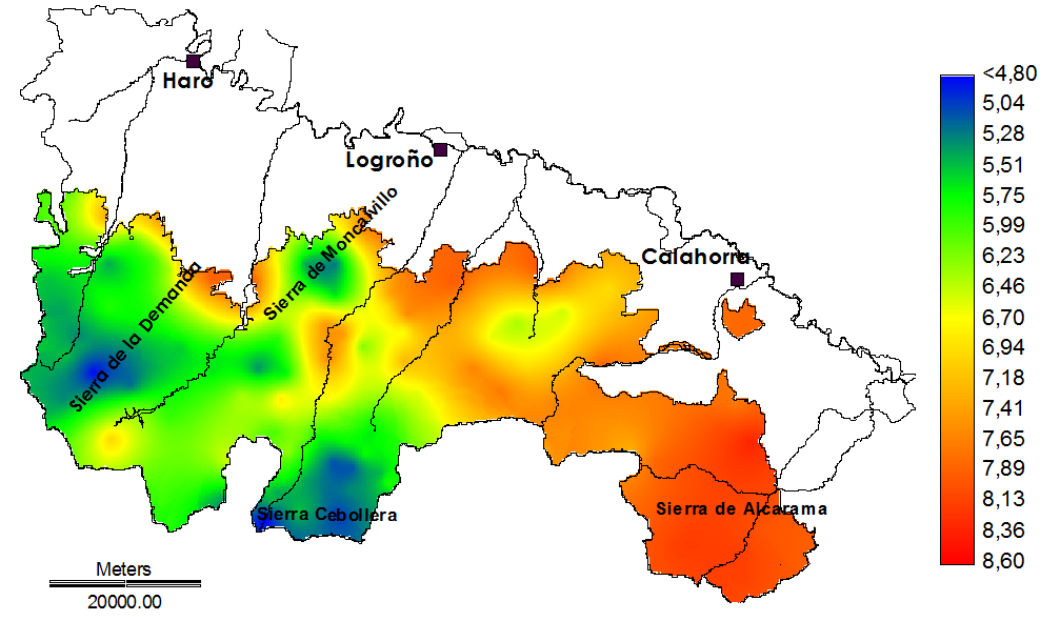

b

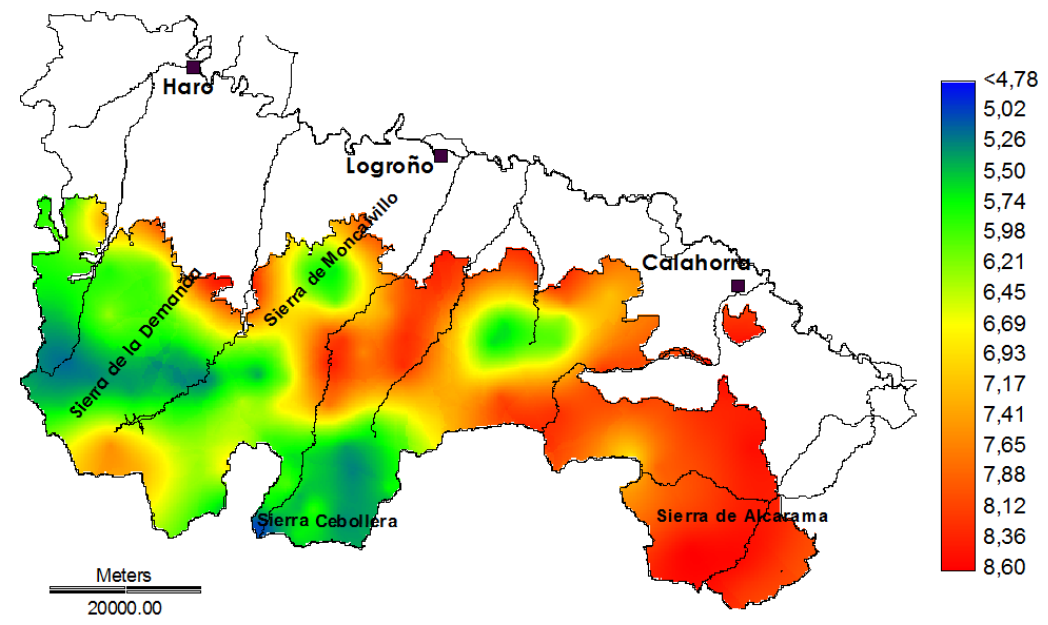

Figure 6. Spatial distribution map of $\mathrm{pH}$ at the surface (a) and in the lower layers (b).

\section{Carbonates}

Table 1 shows the statistical descriptors for carbonate contents both at the surface and at depth. The mean value and robust statistical descriptors, such as the mean, median, maximum, minimum and percentile values, are listed here instead of the most common statistical descriptors (the mean and standard deviation). The large number of null values obtained meant that the common statistical descriptors were not reliable. The distribution is therefore better explained using the robust statistical descriptors (Barona and Romero 1996). For the same reason, we did not perform the KolmogorovSmirnov normal curve test or calculate the asymmetry and kurtosis values.
Table 1 shows that fewer than half of the samples contained $\mathrm{CaCO}_{3}$. In the rest of the samples, the $\mathrm{CaCO}_{3}$ content varied considerably, and even reached high values (65\% in the surface layers). Table 2 shows the mean values for the upper and lower layers compared in pairs. The $\mathrm{CaCO}_{3}$ contents (\%) in the surface and deep layers correlated highly $\left(r^{2}=0.720, p<0.005\right)$. The difference between the mean values for $\mathrm{CaCO}_{3}$ content in the two layers compared was significant, with values being lower in the upper than in the lower layers.

The higher percentage of $\mathrm{CaCO}_{3}$ in the deeper layers together with the large number of null values obtained at surface could be partially explained by the biological activity that takes 
place in the soil. Microorganisms living in the soil give off $\mathrm{CO}_{2}$ and this favours the mobilization of $\mathrm{CaCO}_{3}$ towards the deeper layers. This explains the drainage of carbonates in humid climates and in soils with a filtering humidity regime. It also explains the absence of $\mathrm{CaCO}_{3}$ in acidic soils, as well as its migration in soils with a non-filtering humidity regime in arid and semiarid areas (Porta et al. 2003).

$\mathrm{CaCO}_{3}$ contents presented a large number of null values, both in the upper and lower layers. For this reason, it was not appropriate to obtain distribution maps using "Ordinary Kriging" as we did for $\mathrm{pH}$.

Two maps were produced to illustrate carbonate distributions in the upper layers and another two were produced for the lower layers. The method used in all of these cases was "Indicator Kriging". To design these maps, a closing value or Indicator was assigned to each value. In this way, we calculated the probability of $\mathrm{CaCO}_{3}$ exceeding the assigned value, measured on a scale from 0 to 1 , for each point on the map. In other words, the variable was transformed into a binomial: the lower quantities of the indicator were given a value of 0 and those that were higher or equal to the value of the given Indicator were given a value of 1 . In the first maps of the upper and lower layers (Figures 7a and $7 \mathrm{~b}$ ), the closing value assigned was $0.5 \%$ $\left(\mathrm{I}=0\right.$ when $\% \mathrm{CaCO}_{3} \leq 0.5 \%$ and $\mathrm{I}=1$ starting from that value). This way, it was possible to obtain the probability of a certain percentage of $\mathrm{CaCO}_{3}$, measured on a scale from 0 to 1 .

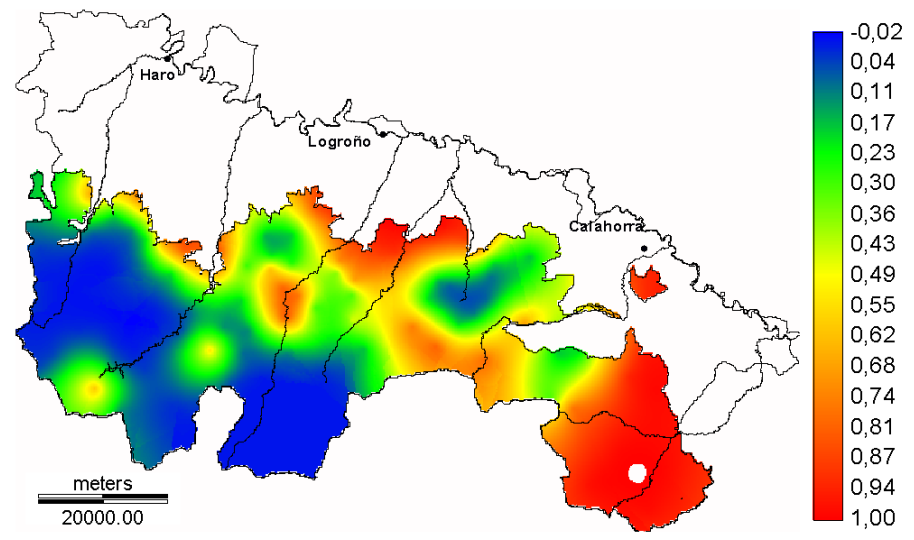

b

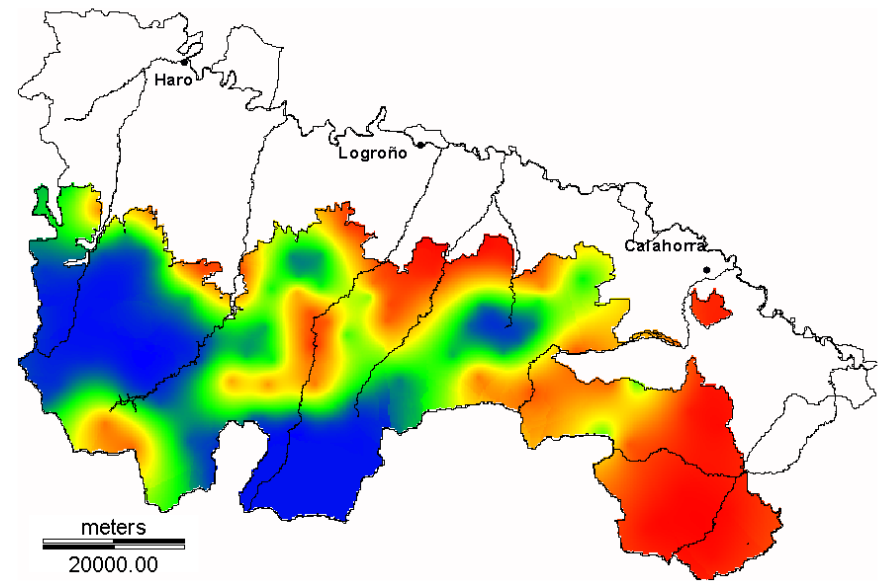

Figure 7. Map showing the spatial distribution of the carbonate fraction in the surface (a) and lower layers (b). 
The second set of maps for the upper and lower levels (Figures $8 \mathrm{a}$ and $8 \mathrm{~b}$ ) take $15 \%$ of the content $\left(\mathrm{I}=0\right.$ when $\left.\% \mathrm{CaCO}_{3} \leq 15 \%\right)$ as the closing value. These maps indicate the probability of finding high $\mathrm{CaCO}_{3}$ contents on a scale from 0 to 1 .

The map in Figure 7a, which indicates the distribution of $\mathrm{CaCO}_{3}$ at the surface, shows that $\mathrm{CaCO}_{3}$ is only present in the eastern half of the area studied. Comparing this map to that for the distribution of $\mathrm{pH}$ at the surface (Figure $6 a)$, it is possible to appreciate the high degree of similarity. $\mathrm{CaCO}_{3}$ is present in the areas with basic pHs. Even so, it was also possible to find high quantities of $\mathrm{CaCO}_{3}$ in other environments. The maps that show the presence of $\mathrm{CaCO}_{3}$ at depth (Figure 7b) and at the surface (Figure 7a) are similar; $\mathrm{CaCO}_{3}$ contents are only higher at depth in certain areas. In the distribution map of $\mathrm{pH}$ in the lower layers (Figure $6 \mathrm{~b}$ ), the $\mathrm{pH}$ is also higher.

Comparing distribution maps for the upper (Figures $7 \mathrm{a}$ and $8 \mathrm{a}$ ) and lower layers (Figures $7 \mathrm{~b}$ and $8 \mathrm{~b}$ ), it is possible to observe that $\mathrm{CaCO}_{3}$ contents are higher at depth, even when above $15 \%$. This was already apparent from comparisons of the mean values (Table 2). This difference between the surface and lower layer values may have been due to the drainage of $\mathrm{CaCO}_{3}$ produced in humid climates, which causes its accumulation in the deeper layers.

a

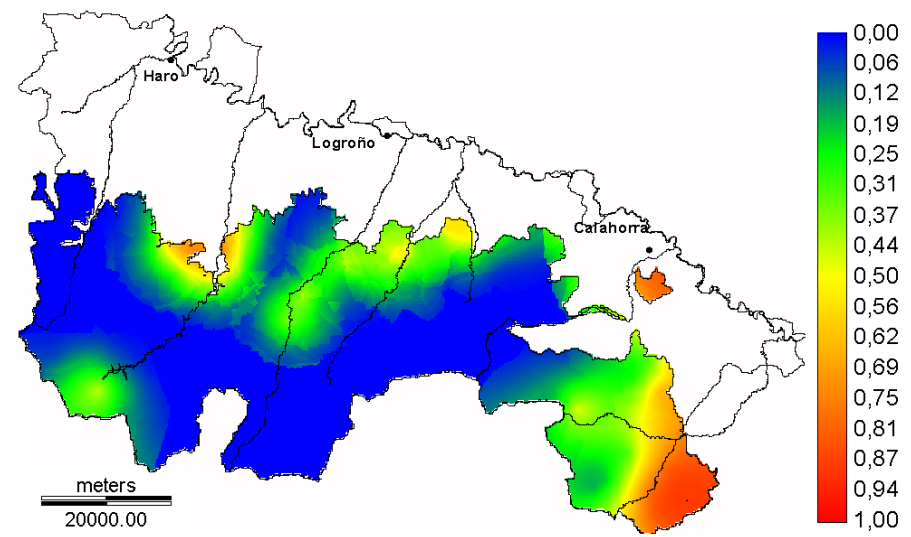

b

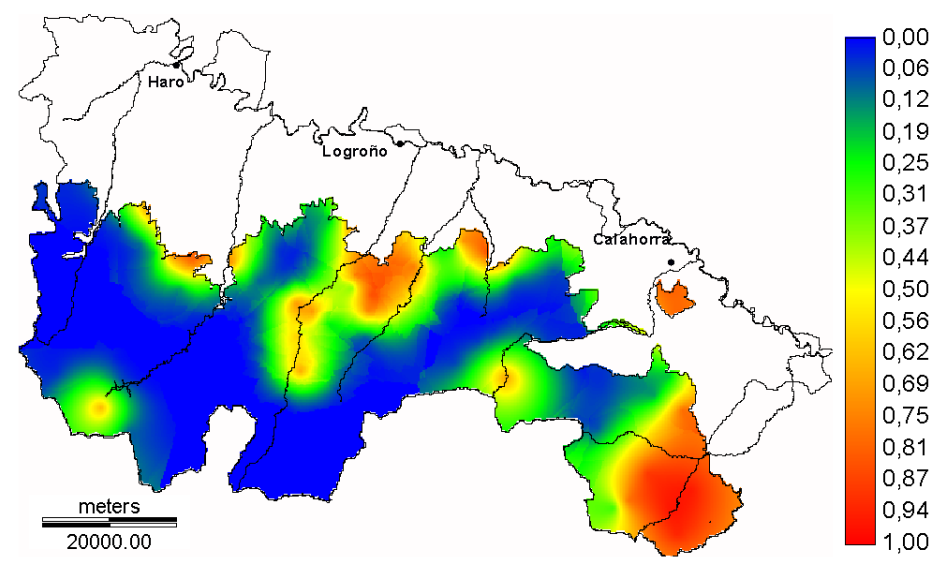

Figure 8. Map showing the spatial distribution of carbonate fractions of $>15 \%$ in the surface (a) and lower layers (b). 


\section{Organic Matter}

Table 1 shows the statistical descriptors for the distribution of organic matter at the surface and at depth. The values obtained from the Kolmogorov-Smirnov test (D) are shown together with the asymmetry and kurtosis coefficients which show whether the distributions follow a normal curve. The D statistic is higher than the critical value indicated by this same test, and the asymmetry and kurtosis tests are positive and also higher than the critical values (Zar 1996): the distribution of organic matter, in the upper and lower layers does not follow a normal distribution. As indicated by the asymmetry coefficient, the distributions are diverted to the right, which means that the mean value is higher than the median. The reviewed literature states that soils with organic matter contents of greater than $2.6 \%$ have good nutrient storage (Purdie 1998). A large percentage of soils in the region have satisfactory levels of organic matter.

From Table 1, it can be deduced that the distribution of organic matter at the surface is close to being binormal, with some extreme values $(>12.0 \%)$, than normal. On the other hand, it can be observed that the distribution of organic matter with depth does not adjust to a normal distribution but to a lognormal one.

Table 2 shows the results for the comparison of mean values of paired up data on organic matter quantities at the surface and at depth. The correlation between the organic matter at the surface and at depth is significant $\left(r^{2}=0.266\right.$, $p<0.005)$. When comparing mean values, the difference is significant, with the organic matter content at the surface layers being much higher.

The percentage of organic matter present at the surface was similar to that reported by Alonso Martirena (1998) for forest soils in Navarra and by McGrath and Zhang (2003) for meadow soils in Ireland. Porta et al. (2003) mention values ranging from 5 to $8 \%$ for meadow soils.

Only the distribution map for organic matter at the surface has been generated (Figure 9) because the organic matter contents in the lower layers were close to 0 in most of the soils sampled and therefore the resulting map would not have been of any interest to the rest of the study.

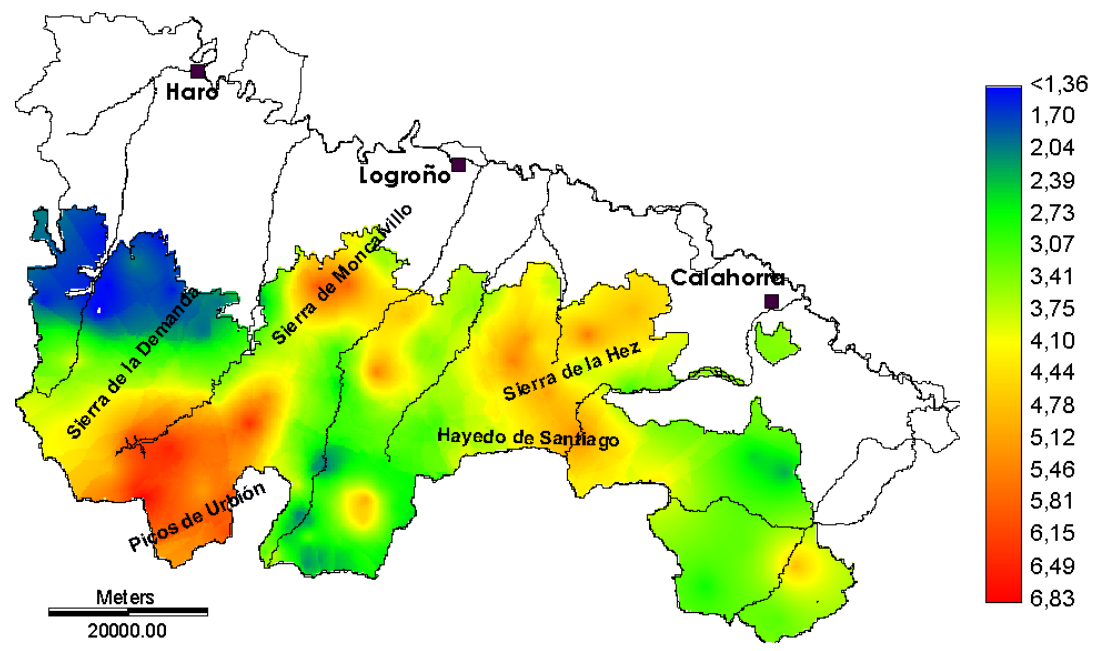

Figure 9. Map showing the spatial distribution of organic matter content in the surface layers. 


\section{Clay fraction}

Table 1 shows the statistical parameters, the D statistic obtained from the Kolmogorov-Smirnov test, and the asymmetry and kurtosis coefficients relating to the clay contents in the upper and lower layers of the soil profile. The D statistic is higher than the critical value for comparison, and the asymmetry coefficient is positive and high for both the upper and lower layers of the soil profile (Zar 1996). In contrast, the kurtosis coefficient is lower than the critical value. The distributions of clay do not adjust to normality, either at the surface or in the lower layers.

Neither of the clay distributions -in the upper and lower layers- follows a normal distribution, though they do present certain resemblances to one.

Table 2 shows the results obtained after comparing mean values of paired up data for clay contents in the surface and lower layers. It can be observed that the correlation between the two contents is high $\left(r^{2}=0.508, p<0.005\right)$ and that there is no significant difference between them. The clay content at the surface is similar to that in the lower layers.

The clay content in the upper layers (Figure 10a and $10 \mathrm{~b}$ ) is higher than in the lower ones in some areas, but generally quite similar. The clay content at depth is similar to that at the surface, though more extreme values may be observed in some areas.

Numerous authors have reported variations in soil $\mathrm{pH}$, soil salinity, cationic exchange capacity, and the availability of other micronutrients, etc. (Wollenhaupt et al. 1994; Häni 1996; Derome and Lindroos 1998; Koptsik et al. 1998; Rusell and Alberti 1998; Vasu et al. 1998; Reimann et al. 2000; Lukina and Nikonov 2001; Lin 2002; Dai et al. 2004). Variations in the parameters analyzed could therefore also be expected to produce variations in these other parameters.

a

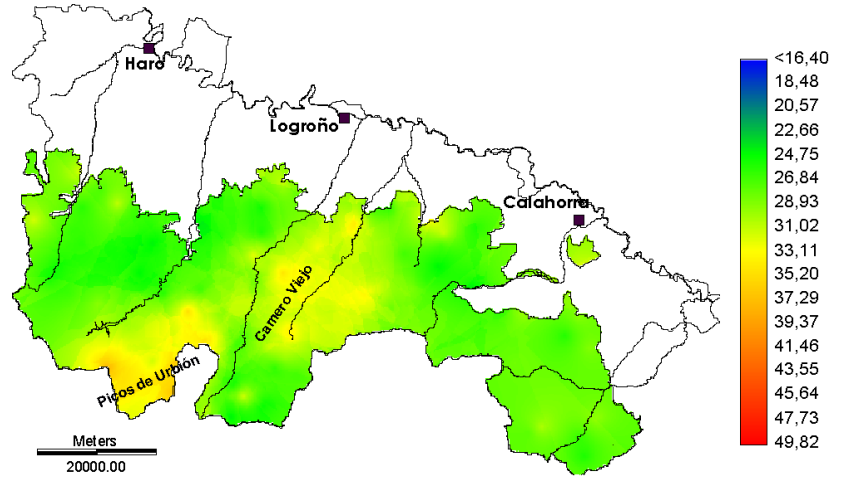

b

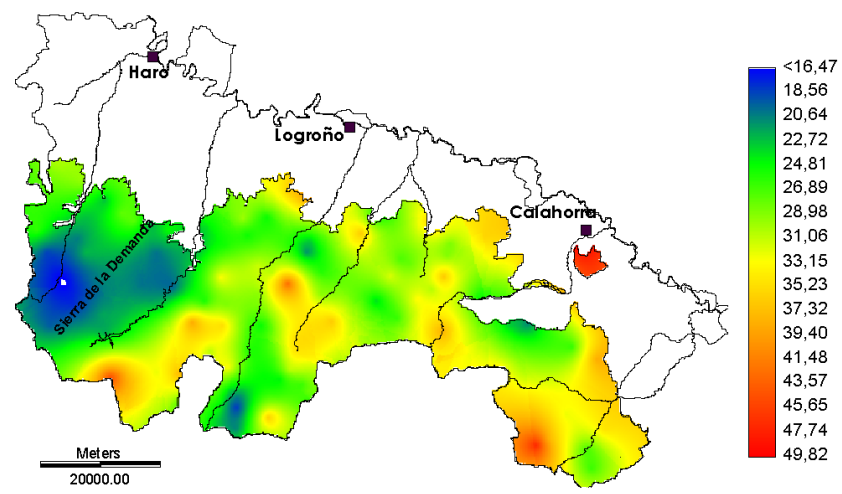

Figure 10. Map of the spatial distribution of clay fraction content in the surface (a) and lower layers (b). 


\section{Conclusions}

In this study, geostatistical methods were used to reveal the spatial variability of certain soil properties. Half of the samples studied did not contain $\mathrm{CaCO}_{3}$, while in the others, the percentage of $\mathrm{CaCO}_{3}$ varied considerably, reaching percentages as high as $65 \%$ in the surface layers. Two distinct areas could be differentiated: one acidic and one basic. The clay content in the surface layers was similar to that in the deeper ones. Finally, the organic matter levels in the surface layers presented an average content of $3.9 \%$, with a range of from 0.3 to $17.5 \%$. The greatest variations were determined by soil type, parent material composition, and vegetation type.

This study has shown that the degree of uncertainty related to spatial distribution can be reduced by improving information relating to field variability and using classical statistics tools and geostatistical procedures adjusted to the variability patterns. Mapping the spatial distribution of $\mathrm{pH}$, carbonates, organic matter, and clay fractions in soils through geostatistical studies and the use of GIS should facilitate and help to improve our understanding of the state of the soil properties analyzed and be especially useful for environmental soil management plans. These contour maps of soil property variability could be used to improve future sampling designs, but their quality would need to be examined in greater detail for local management decisions.

\section{REFERENCES}

- Alonso Martirena JI. 1998. Estudio del Contenido y Distribución de los Metales Pesados en Suelos de Navarra (Cadmio, Cobre, Manganeso, Níquel, Plomo y Cinc). Tesis Doctoral. Pamplona: Universidad de Navarra.

- Anne A. 1945. Dosage rapide du carbone organique dans les sols. Ann. Agron. 2: 161-172.

- Batjes NH. 1996. Total carbon and nitrogen in the soils of the world. European Journal of Soil Science 47(2):151-163.

- Batjes NH. 1997. A world dataset of derived soil properties by FAO-UNESCO soil unit for global modelling, Soil Use and Management 13:9-16.

- Bárdossy A, Lehmann W. 1998. Spatial distribution of soil moisture in a small catchment. Part 1: Geostatistical Analysis. Journal of Hidrology 20:1-15.

- Barona A, Romero F. 1996. Distribution of metals in soils and relationships among fractions by principal component analysis. Soil Technology 8:303-319.

- Basso-Figuera C, Basso-Figuera C, Schaffer B, Crane J, Coll AM, Bryan HH. 1995. Mineral nutrient content, growth and yield of papaya as influenced by trench depth and municipal solid waste compost. Tropical Agriculture 72:231-235.

- Bocchi S, Castrignanò A, Fornano F, Maggiore T. 2000. Application of factorial kriging for mapping soil variation at field scale. European Journal of Agronomy 13:295-308

- Brouder SM, Hofmann BS, Morris DK. 2005. Mapping soil $\mathrm{pH}$ accuracy of common soil sampling strategies and estimation techniques. Soil Sci. Soc. Am. J. 69:427-442.

- Burrough PA, McDonnell RA. 1998. Principals of Geographical Information Systems. $2^{\text {nd }}$ edition. Oxford: Oxford University Press.

- Casas Sainz AM, Gil Imaz A, Muñoz Jiménez A. 2001. La Rioja, Geología y Paisaje. Zubía 13:11-40.

- Castrignanò A, Giugliarini L, Risaliti R, Martinelli N. 2000. Study of spatial relationships among some soil physico-chemical properties of a field in central Italy using multivariate geostatistics. Geoderma 97:39-60.

- Charman PEV. 2000. Other forms of soil degradation. In: Charman PEV, Murphy BW, editors. Soils: Their Properties and Management ( $2^{\text {nd }}$ ed.). Oxford, UK: Oxford University Press. 
- Corwing DL, Wagenet RJ. 1996. Applications of GIS to the modeling of nonpoint pollutants in the vadose zone: a conference overview. Journal of Environmental Quality 25:403-411.

- Council Directive 92/43/EEC on the Conservation of natural habitats and of wild fauna and flora and the law 4/98. 1992. Official Journal of the European Communities L 206:7-50.

- Dai J, Becquer T, Rouiller JH, Reversat G, BernhandReversat F, Lavelle P. 2004. Influence of heavy metals on $\mathrm{C}$ and $\mathrm{N}$ mineralisation and microbial miomass in $\mathrm{Zn}-, \mathrm{Pb}, \mathrm{Cu}-$, and $\mathrm{Cd}$ - contaminated soils. Applied Soil Ecology 25:99-109.

- Derome J, Lindroos AJ. 1998. Effects of heavy metal contamination on macronutrient availability and acidification parameters in forest soil in the vicinity of the Harjavalta Cu-Ni Smelter, SW Finland. Environmental Pollution 99: 225-232

- Ebbinghaus E, Kreeb KH, Weinmannkreeb R. 1997. GIS supported monitoring long-termed urban trace element loads with bark of Aesculum hippocastanum. Journal of Applied Botany-Angewandte Botanik 715(6):205-211.

- Facchinelli A, Sacchi E, Mallen L. 2001. Multivariate statistical and GIS-based approach to identify heavy metal sources in soils. Environmental Pollution 114:313-324

- FAO-ISRIC-ISSS. 2006. World reference base for soil resources. A framework for international classification, correlation and communication. World soil resources reports 103. Rome. $132 \mathrm{p}$.

- FAO. 2006. Guidelines for soils description. $4^{\text {th }}$ ed. Rome: FAO/UNESCO

- Fenton G. Helyar KR. 2000. Soil acidification. In: Charman PE, Murphy BW, editors. Soils: their properties and management. $2^{\text {nd }}$ ed. Oxford, UK: Oxford University Press.

- Fernández Aldana R, Lopo Carramiñana L, Rodríguez Ochoa R. 1989. Mapa Forestal de La Rioja. Serie de Estudios n 18. Logroño: Gobierno de La Rioja.

- Ferreira A, Inacio MM, Morgado L, Batista MJ, Ferreira L, Pereira V, Pinto MS. 2001. Low-density geochemical mapping in Portugal. Applied Geochemistry 16:1323-1331.

- García Ruiz JM. 1994. Caracteres generales del relieve. In: García Ruiz JM, Arnáez Vadillo J, editores. Enciclopedia de la Rioja. V. 1. Geografía física. Logroño: Caja de Ahorros de la Rioja. p. 36-38.
- Gee GW, Bauder JW. 1986. Particle-size analysis. In: Klute A, editor. Methods of Soil Analysis. Part 1. Physi$\mathrm{cal}$ and mineralogical methods. $2^{\text {nd }}$ ed. Agronomy Monograph No.9. Madison (USA): ASA-SSSA. p 383-411.

- Häni H. 1996. Soils analysis as a tool to predict effects on the environment. Communications in Soil Science and Plant Analysis 27(3-4):289-306.

- Henry M, Valentini R, Bernoux M. 2009. Soil carbon stocks in eco-regions of Africa. Biogeosci Discuss 6:797-823.

- Ingamells CO. 1974. Control of Geochemical Error Through Sampling and Subsampling Diagrams. Geochemical et Cosmochemica Acta. Vol. 38:1255-1237.

- Koptsik GN, Nedbaev NP, Koptsik SV, Pavlyuk IN. 1998. Heavy metal pollution of forest soils by atmospheric emissions of Pechenganikel Smelter. Eurasian Soil Science 31(8):421-428.

- Lapen DR, Topp GC, Hayhoe HN, Gregorich EG, Curnoe WE. 2001. Stochastic simulation of soil strength/ compaction and assessment of corn yield risk using threshold probability patterns. Geoderma 104:325343.

- Laslett GM, McBratney AB, Pahl PJ, Hutchinson MF. 1987. Comparison of several spatial prediction methods for soil pH. J. Soil Sci. 38:325-341.

- Lin YP. 2002. Multivariate geostatistical methods to identify and map spatial variations of soil heavy metals. Env. Geology 42(1):1-10.

- Lindsley CM, Bauer FC. 1929. Test your soil for acidity. Circular 346. College of Agriculture and Agricultural Experiment Station. Champaign (IL, USA): University of Illinois.

- Lukina N, Nikonov V. 2001. Assessment of environmental impact zone in the Kola Peninsula Forest Ecosystem. Chemosphere 42:19-34.

- McBratney AB, Pringle MJ. 1999. Estimating average and proportional variograms of soil properties and their potential use in precision agriculture. Precis. Agric. 1:125-152.

- McGrath D, Zhang C. 2003. Spatial distribution of soil organic carbon concentrations in grassland of Ireland. Applied Geochemistry, 18:1629-1639.

- Miller JN, Miller JC. 2002. Estadística y quimiometría para química analítica. $4^{\text {th }}$ ed. Madrid: Prentice Hall. 
- Mohamed MY, Abdo BM. 2011. Spatial variability mapping of some soil properties in El-Multagha agricultural project (Sudan) using geographic information systems (GIS) techniques. Journal of Soil Science and Environmental Management 2(2):58-65

- Mueller TG, Pierce FJ, Schabenberger O, Warncke DD. 2001. Map quality for site-specific fertility management. Soil Sci. Soc. Am. J. 65:1547-1558.

- Nielsen DR, Bouma J, editors. 1985. Soil spatial variability. Proceedings of a Workshop of the ISSS and the SSSA. 1984 Nov 30- Dec 1; Las Vegas, USA. Wageningen, The Netherlands: Pudoc.

- Nuñez Olivera E, Martínez Abaigar J. 1991. El clima de La Rioja. Análisis de precipitaciones y temperaturas. Logroño: Gobierno de La Rioja.

- Ozores-Hamton M, Schaffer B, Bryan H. 1994. Nutrient concentrations, growth and yield of tomato and squash in municipal solid waste amended soil. Hort Science 29:785-788.

- Pal S, Panwar P, Bhatt VK. 2010. Analysis and interpretation of spatial variability of soil properties is a keystone in site-specific management. Indian Journal of Soil Conservation 38(3):178- 183.

- Pitard FF 1989. Pierre Gy's Sampling Theory and Sampling Practice. Boca Raton, FL: CRC Press.

- Porta Casanellas J, López Acevedo M, Roquero de Laburu C. 2003. Edafología para la agricultura y el medioambiente. $3^{\text {a }}$ Ed. Madrid: Mundi-Prensa. 929 pp.

- Post WM, Peng TH, Emanuel WR, King AW, Dale VH, DeAngelis DL. 1990. The global carbon cycle. American Scientist 78:310-326.

- Purdie B. 1998. Understanding and interpreting soil chemical and physical data. In: Moore G, editor. Soilguide: A Handbook For Understanding and Managing Agricultural Soils. Agriculture Western Australia Bulletin No. 4343. Perth, Australia: Department of Agriculture.

- Reimann C, Banks D, De Caritat P. 2000. Impacts of airborne contamination on regional soil and water quality: the Kola Peninsula, Russia. Environmental Science and Technology 34:2727-2732.

- Robinson TP, Matternicht G. 2006. Testing the performance of spatial interpolation techniques for mapping soil properties. Comput Electron Agric 50:97-108.

- Russell DJ, Alberti G. 1998. Effects of long-term, geogenic heavy metal contamination on soil organic matter and microarthropod communities, in particular Collembola. Applied Soil Ecology 9:483-488.
- SCS-USDA. 1972. Soil Survey investigations report $\mathrm{n}^{\circ} 1$. Soil survey laboratory methods and procedures for collecting soil samples. Washington D.C.: US. Govt. Printing Office.

- Sharma P, Shukla K, Mexal G. 2011. Spatial variability of soil properties in agricultural fields of southern New Mexico. Soil Science 176(6): 288-302.

- Vasu K, Sahul-Mameed A, Velayurdham KT. 1998. Accumulation of plant nutrients and heavy metals in soils neighbouring an industrial area. Indian Journal of Environmental Health 40(2):189-196.

- Walker JP, Houser PR. 2001. A methodology for initializing soil moisture in a global climate model: assimilation of near-surface soil moisture observations. Journal of Geophysical Research 106:11761-11774.

- Wang YQ, Shao MA. 2011. Spatial variability of soil physical properties in a region of the loess plateau of PR China subject to wind and water erosion. Land Degrad. Develop. doi: 10.1002/ldr.1128.

- Wollenhaupt NC, Wolkowski RP, Clayton MK. 1994. Mapping soil test phosphorus and potassium for variable-rate fertilizer application. J. Prod. Agric. 7:441448.

- Wollenhaupt NC, Mulla DJ, Gotway CA. 1997. Soil sampling and interpolation techniques for mapping spatial variability of soil properties. In: Pierce FJ, Sadler EJ, editors. The state of site-specific management for agriculture. Madison, WI (USA): ASA, CSSA, SSSA. p. 19-53.

- Zar J H. 1996. Biostatisitcal Analysis. $3^{\mathrm{a}}$ ed. New Jersey: Prentice Hall International Editions. 256 p. 